\title{
MAREJADA: EL OTRO LADO DEL DRAMA HUMANO
}

\author{
Lourdes Ortiz Sánchez
}

\begin{abstract}
RESUMEN
En este artículo, se hace un análisis sobre la situación contemporánea de algunos grupos migratorios en España. Se hace un recuento del drama humano de los cientos de emigrantes del norte de África y del África subsahariana que atraviesan el mar hacinados en minúsculas pateras, llegando exhaustos o muriendo en la travesía. Plantea también una reflexión sobre el destino de esas pobres gentes que huyen de un continente sin esperanzas, creyendo dirigirse al Paraíso y, o mueren en el trayecto, o son devueltos a sus respectivos países.

Palabras clave: emigrantes, indocumentados, conflictos, pateras, travesías.
\end{abstract}

\begin{abstract}
In this article, the author analyses the contemporary situation that some migratory groups confront in Spain. The human drama that thousands of people from the North of Africa and the Subsaharan Africa daily experience when they cross the ocean in small "pateras" is shocking. Those people arrive exhausted or they die in the process. All these events demand a serious reflection about the destiny that these poor people face when they leave their land looking for paradise, however, many die in the process or they are send back to their original countries.

Key words: immigrants, undocumented, conflicts, pateras, travel.
\end{abstract}

\section{Marejada}

En este trabajo, hablaré de los estímulos que, como escritora, recibo de la realidad contemporánea de mi país. Y entre esos estímulos, el hecho de una sociedad cambiante. Una sociedad que en los últimos años se ha ido rápidamente transformando, dado el vertiginoso desarrollo económico, lo cual plantea nuevos problemas a la población: problemas de

Licda. Lourdes Ortiz Sánchez. Catedrática de Teoría de Historia del Arte en la Real Escuela Superior de Arte Dramático, España.

Correo electrónico: lourortiz@yahoo.es

Recepción: 4- 1- 2010

Aceptación: 29- 1- 2010 
integración, de absorción de la gran masa de emigrantes venidos tanto de los antiguos países del Este, que ahora pasan a formar parte de la Comunidad Europea, como, y sobre todo, de los procedentes del continente africano.

España había sido desde hace mucho tiempo, sobre todo a lo largo del siglo XIX y en gran parte del siglo XX, un país de emigración, que desde la expulsión de la población judía en tiempos de los Reyes Católicos (s. XV) y de los moriscos a principios del s. XVII apenas había tenido aportación de gentes de otros ámbitos o culturas; a diferencia de Francia, Alemania o, desde luego, Inglaterra. Ese aislamiento se ha modificado radicalmente en los últimos años, influyendo de un modo decisivo y novedoso en el ámbito de las relaciones cotidianas. Esa afluencia masiva de emigrantes necesaria para el desarrollo económico -los recién emigrantes ocupan puestos de trabajo que ya non queridos, ni aceptados por los españoles- ha provocado, sin embargo, actitudes que sin llegar a ser xenófobas pueden considerarse problemáticas y suponen un aumento de la desconfianza hacia los recién llegados.

Por otro lado, el drama humano de los cientos de emigrantes del norte de África y del África subsahariana, que atraviesan el mar hacinados en minúsculas pateras, llegando exhaustos o muriendo en la travesía, plantea también una reflexión sobre el destino de esas pobres gentes que huyen de un continente sin esperanzas, creyendo dirigirse al Paraíso, pero mueren en el trayecto, son devueltos a sus respectivos países -siempre que se sepan de donde proceden, ya que la mayoría llegan sin documentación alguna- o quedan en una situación delicada e irregular, porque no tienen papeles, ni posibilidad de llegar a tenerlos, pues para conseguir un trabajo necesitan precisamente esos papeles. Es gente destinada a deambular por las ciudades y a vivir una situación desesperada, aceptando pequeños trabajos ilegales, siempre muy mal pagados, o cayendo, en algunos casos en la delincuencia para poder sobrevivir, lo que aumenta la desconfianza de la población y el rechazo.

Todo esto crea una situación inédita que se acentúa y complica en estos momentos de recesión económica y de crisis, ya que muchos de esos recién llegados pasan a integrar largas colas del paro. Sería impensable que todos estos factores que inciden en las formas de vida no interesen al escritor o la escritora que mira hacia la realidad para intentar contarla ya transfigurada en hecho literario. Es difícil no sentirse impresionado, aunque tendamos a cerrar los ojos, por ese gotear diario de cuerpos de hombres jóvenes, desfallecidos tras la travesía, deshidratados, enfermos, que día tras día, como si fuera una pesadilla contemplamos en el telediario: madres jóvenes embarazadas, madres con hijos recién nacidos, muchachos que no han cumplido los quince años u hombres hechos y derechos que huyen de su país en busca de mejores condiciones de vida y que suelen arribar en una situación lamentable. Son recogidos muchas veces en medio del océano por los guardacostas o las patrullas de vigilancia y llegan a puerto teniendo que ser asistidos inmediatamente por la Cruz Roja, antes de ser congregados en una especie de campos de concentración, hasta que son devueltos a su país o abandonados en España, cuando no se sabe de donde proceden, por no tener documentación alguna.

No es un tema político, sino humano con todas sus facetas. Y hay que ser muy duro de corazón para no verse afectado por las reiteradas imágenes que recibimos día tras día. Y lo peor es que, por muchas medidas que el gobierno imponga para evitar esa sangría, no parece que vaya a tener fin, mientras se mantengan las condiciones de vida en el continente africano y las muchas guerras que allí se desencadenan entre las tribus y los distintos intereses de las grandes naciones en conflicto. El Estrecho es una zona del mar Mediterráneo muy pequeña. Pocas millas separan España de África y la tentación del viaje hacia el Paraíso, que imaginan, un acicate para lanzarse a esas terribles y cotidianas travesías. 
Releyendo a los grandes novelistas norteamericanos de principios del siglo XX, Dos Passos, Dreiser, e incluso Scott Fitzgerald, uno/a encuentra similitudes entre aquella sociedad cambiante y en rápido progreso de la construcción y los negocios, con las masas de hombres y mujeres recién llegadas buscando el modo de integrarse en la sociedad y la proliferación de nuevos conflictos que traen como consecuencia el nacimiento de las mafias. Algo así, en pequeña escala, se está produciendo en nuestro país de un modo acelerado. O más bien se ha producido. Crecimiento rápido que ahora con la crisis económica puede llevar, como ocurrió en América en el 29, a un espectacular choque, un final paradójico de las esperanzas acumuladas en esas masas, que han aprovechado esos años para un consumo desenfrenado y unas hipotecas a las que difícilmente pueden ahora responder. Empobrecimiento por tanto de las clases medias y paro para los trabajadores recién llegados, tanto para aquellos que tienen papeles legales, como para todos aquellos que trabajan clandestinamente y que han contribuido con sus sueldos de miseria, quiérase o no, al rápido enriquecimiento del país ¿No es acaso un tema para la literatura y para la reflexión?

Como reflexión sobre este tema me permito presentar este texto con imágenes poderosas que nos plantean el otro lado de este drama humano.

\section{Imágenes}

Una mancha de rojo sobre la arena. Al aproximarse la cámara vemos los rostros doloridos emergiendo de las mantas, las manos tan oscuras, los ojos gigantes, donde brilla el blanco como una pregunta y se vislumbra el pánico. Así día tras día. La captura o lo que eufemísticamente llaman "salvamento". Los cuerpos ateridos, temblando, el miedo en la mirada, el ansia. ¿Qué ocurrirá ahora? Cientos, miles de navegantes espontáneos, de aventureros del hambre o de la esperanza, dispuestos a enfrentarse, apilados en una diminuta "patera", en una lancha, a veces de juguete, a las olas del mar, al sol ardiente, a la incertidumbre, a noches y días perdidos en el océano. Balsa de la Medusa, donde los cuerpos flaquean, ateridos, sedientos, donde unos resisten y otros perecen, siendo arrojados al mar para hacer sitio, como un homenaje silencioso y no querido a aquel naufragio que nos contara Byron en su D. Juan. La sed, la sed. Falta de agua, falta de todo, pero el anhelo todavía, tal vez, tal vez...

En la playa o en el puerto, se amontonan ahora los hombres, los niños, las mujeres -muchas embarazadas- cubiertos con las mantas rojas. Los más delicados, los más débiles, aquellos que apenas pueden ya andar o resistir han sido trasladados a centros sanitarios para ser atendidos por la Cruz Roja. Los otros esperan para, después del rápido examen, ser recluidos en centros de internamiento, nueva e incómoda palabra para denominar a esos campos de concentración, donde a muchos les aguarda la repatriación y a otros sin papeles, ni nacionalidad conocida una presunta libertad absurda que les llevará a deambular por las ciudades y los pueblos, intentando conseguir limosna, un mendrugo de pan o un trabajo ilegal y mal pagado. Se dice que la mayoría arrojan antes de partir sus papeles de identidad para no ser devueltos a su país de origen, sobre todo aquellos que provienen de un país con el que España tiene firmado un tratado de extradición, lo que garantiza el que serán devueltos.

Junto a las machas rojas, el reflejo brillante de las bolsas doradas o negras que guardan a los muertos. Aquellos que no lograron sobrevivir; algunos llegan en la pateras, otros, los arrojados al mar, arriban después o antes a las playas: cuerpos escultóricos, inertes, que sorprenden a veces a los veraneantes, a los turistas que reposan plácidamente en la tumbona o en el chiringuito mientras 
toman el sol o el aperitivo de la una de la tarde. Hay un cementerio, construido expresamente para los sin nombre, los muertos sin identidad. Las estadísticas, que siempre mienten, hablan de quince mil. Pero es imposible llegar a saber cuántos de verdad han muerto en la travesía.

Cuantos son esperados inútilmente por sus familias al otro del mar. Madres, esposas sin hijos o marido que aguardan, todavía con esperanza, una llamada que les confirme que todo ha ido bien.

Hay muchas otras imágenes del después. De la lucha casi imposible por la supervivencia, del horror, del hacinamiento, del hambre, de las carreras, de las humillaciones, de los desplantes y del racismo y el desprecio con que, por lo general, son acogidos en un país no acostumbrado hasta hace muy poco a recibir emigrantes. Los que llegan de Latinoamérica se acaban integrando con más facilidad. El color de su piel y la lengua facilitan la búsqueda y el encuentro de trabajo, aunque sea mal pagado. Pero la emigración que llega de África, aquella que en penosas condiciones se atreve a pasar el Estrecho lleva en su piel la mancha distintiva, que les impide pasar inadvertidos entre la multitud. Algunos lo consiguen y se integran en los invernaderos, en el trabajo duro de la construcción o en la pesca. Pero la mayoría viven "flotando", malviviendo, explotados o sostenidos por las mafias o refugiados en los albergues, donde se hacinan por las noches los sin techo y los recién llegados. Muchas desoladas imágenes, demasiadas. Que se acentúan ahora con la crisis económica y el creciente paro. Y no hay perspectivas de que la cosa vaya a cambiar. 